\title{
Governance approach to the prioritization of sustainable development goals in the city of Medellin (Colombia)
}

\author{
Abordagem de governança para a priorização de metas \\ de desenvolvimento sustentável na cidade de Medellín \\ (Colômbia)
}

Abraham Londoño Pineda [a] [D, Jose Alejandro Cano [a] [D, Mirosława Czerny [b] [D

[a] University of Medellin, Medellín, Colombia

[b] University of Warsaw, Warsaw, Poland

How to cite: Pineda, A. L., Cano, J. A., \& Czerny, M. (2021). Governance approach to the prioritization of sustainable development goals in the city of Medellin (Colombia). urbe. Revista Brasileira de Gestão Urbana, v.13, e20200288. https://doi.org/10.1590/2175-3369.013.e20200288

\begin{abstract}
This article proposes a governance approach for the prioritization of sustainable development goals (SDGs) in the city of Medellín (Colombia, South America). The governance approach proposed in this study stems from the articulation of technical and participatory approaches. The technical approach took as reference the document CONPES 3918, which defines the national sustainable development agenda in Colombia. The participatory approach was supported by the Medellín Citizen Perception Survey, which reflects the most important aspects of the quality of life for citizens. The results indicate that priorities for sustainable development in Medellín should be oriented to SDG 17, SDG 3, SDG 8, SDG 5, and SDG 4. The consistency test (CR) indicates the instrument applied is consistent.
\end{abstract}

Keywords: Governance approach. SDG prioritization. Subnational level. Urban level.

\section{Resumo}

Este artigo propõe uma abordagem de governança para a priorização dos objetivos de desenvolvimento sustentável (ODS) na cidade de Medellín (Colômbia, América do Sul). A abordagem de governança proposta neste estudo decorre da articulação de abordagens técnicas e participativas. A abordagem técnica tomou como referência o documento CONPES 3918, que define a agenda nacional de desenvolvimento sustentável na Colômbia. A abordagem participativa foi apoiada pela Pesquisa de Percepção do Cidadão de Medellín, que reflete os aspectos mais importantes da qualidade de vida dos cidadãos. Os resultados indicam que as prioridades para o desenvolvimento sustentável em Medellín devem ser orientadas para os ODS 17, ODS 3, ODS 8, ODS 5 e ODS 4. O teste de consistência (CR) indica que o instrumento aplicado é consistente.

Palavras-chave: Abordagem de governança. Priorização dos ODS. Nível subnacional. Nível urbano. 


\section{Introduction}

In September 2015, the United Nations General Assembly launched the 2030 Agenda of the Sustainable Development Goals (SDGs), which is considered a more ambitious proposal than its predecessor (Millennium Development Goals - MDGs), as this includes 17 goals, 169 targets, and 232 indicators (Srivastava, 2018; Londoño \& Cano, 2021); and since then, the prioritization of SDGs has become a challenge for different governments (Londoño \& Cruz, 2019). For some authors, the priorities of the SDGs must be aimed at ending poverty, preserving the environment and guaranteeing prosperity in the world (Banerjee et al 2019), while other authors consider it important to address each goal individually. For instance, Asi \& Williams (2018) focused on SDG 3, Nam-Chol \& Kim (2019) studied the indicators necessary to achieve SDG 7, and Vanham et al. (2018) highlighted the importance of achieving SDG 6. However, this article proposes a comprehensive approach to the SDGs aligned with works comprehensively addressing the 17 SDGs such as the work of Biggeri et al. (2019) which considers the design of an index collecting the interactions between the 17 SDGs, and the work of Sachs et al. (2019) that is aimed at achieving all the SDGs mediated by the following transformations: education, gender and inequality (Transformation 1), health, well-being and demography (Transformation 2), energy decarbonization and sustainable industry (Transformation 3), sustainable food, land, water and oceans (Transformation 4), sustainable cities and communities (Transformation 5), and digital revolution for sustainable development (Transformation 6).

Thus far, the prioritization of sustainable development problems has been related to the development needs of different countries. This explains why in developing countries the priorities and availability of indicators have been oriented to social and economic problems like poverty and unemployment, while in developed countries it is easier to find environmental indicators present (Boggia \& Cortina, 2010). This work proposes an alternative prioritization of SDGs using a governance approach, which is based on technical and participatory approaches. Typically, the technical approach has predominated in the prioritization of SDGs, where governments are based on a series of objective or scientific indicators (Londoño, 2018). However, with the $21^{\text {st }}$ century being "the century of the people" (Novo, 2009), there is evident interest in linking the perceptions of stakeholders to SDG prioritization, which is known as the participatory approach (Londoño \& Cruz, 2019). Therefore, this article aims to propose a methodology for the prioritization of SDGs at the sub-national level following a governance-oriented approach, which is supported by objective criteria, but with broader participation of stakeholders.

To achieve this purpose, Section 2 addresses the theoretical framework justifying the choice of the governance approach and discussing the importance of this methodology in overcoming remaining gaps in SDG prioritization on a subnational scale. Section 3 presents the methodological proposal at a subnational scale applied in the city of Medellín (Colombia). It uses the analytical hierarchy process (AHP) to articulate the SDG framework (Technical Approach) with a life quality survey of that city (Participatory Approach), thus facilitating government action regarding sustainable development (Governance Approach). Sections 4, 5 , and 6 respectively show the results, discussions, and main conclusions of this work.

\section{The governance approach to prioritizing SDGs at the subnational level}

Commonly, the technical approach has predominated in the prioritization of sustainable development topics and indicators because it is supported by objective indicators and measurements of the economic, social, and environmental dimensions (Lyytim€aki et al, 2014) to support political decision-making from a scientific base (Mineur, 2007). This approach aims to enhance efficiency, which takes precedence over the participatory approach (Moreno et al., 2014). In the participatory approach, the perceptions of the stakeholders are linked (Holden, 2011), since, for better political action, it is necessary to know and understand the value system, as well as the requirements, concerns, and expectations of those who constitute the territories (Moreno \& Fidélis, 2015). 
On the other hand, the governance approach explores the prioritization of issues related to sustainable development from government contexts (Holman, 2009). In this regard, Kardos (2012) states that governance represents how power is exercised in the management of economic, social, and environmental resources, contributing to the development of a country. To achieve this purpose, the public administration requires a long-term commitment, since on many occasions the governments of the moment are focused solely on showing their short-term management but not on building a long-term vision that guarantees a commitment to sustainable development (Cassar et al. 2013). Therefore, it is necessary to articulate governance and sustainable development.

In this regard, Moreno \& Fidélis (2012) define governance for sustainable development as the set of institutionalized patterns by which sustainable-development policies can be interpreted and applied. The foregoing implies that the use of objective or scientific indicators does not guarantee sustainability (Samuel et al. 2013), but additionally requires the management of a complex system constituted of various agents with varied interests. Thus, the governance approach for sustainable development must focus on the link between the technical and participatory vision. However, it should be clarified that this relationship does not precisely obey a linear model, since it is expected that tensions will appear between participating agents (Etzkowitz \& Leydesdorff, 2000).

This work focuses on a governance approach for sustainable development, which articulates technical and participatory approaches (Moreno \& Fidélis, 2012). However, governance for sustainable development tends to achieve a balance between economic growth, protection of the environment, and improvement in human development. For this, it is essential that governments take measures that contribute to reducing carbon dioxide emissions (Omri \& Mabrouk, 2020), and the management of the SDGs can represent a way to achieve this objective. Additionally, in the governance approach for sustainable development, it is necessary to consider elements of collaborative governance, since its achievement requires the participation of multiple stakeholders (Vazquez-Brust et al., 2020). In this sense, citizen participation is one of the most determining factors for the improvement of the quality of life and one of the conditions for subnational entities, like cities, to advance towards the fulfillment of the SDGs (De Guimarães et al., 2020). Consequently, urban governance processes that pursue compliance with the SDGs must transcend topdown models and move towards bottom-up models, in which citizen participation is essential (Aina et al., 2019). The present study uses both approaches, since in the technical approach (indicators from the CONPES 3918 document) the top-down model predominates, while the bottom-up model predominates in the participatory approach obtained from the quality-of-life survey since the citizens define the most crucial aspects for their quality of life.

Both the 2030 Agenda and the Paris Agreement created a framework for action on sustainable development at the national level (Sachs et al., 2019). Therefore, subnational governments face different alternatives like selecting the 232 indicators of the 2030 agenda, relying on the national sustainable development agenda, drawing their subnational agenda, among others. This study proposes to use the national sustainable development agenda at the sub-national level and prioritize the SDGs according to the characteristics, needs, and requirements of each locality to replace the management of the 232 indicators of the 2030 Agenda at the subnational level.

One of the main limitations at the subnational level is the availability of relevant indicators to assess compliance with the SDGs (Moreno \& Fidélis, 2015), especially in developing countries (Londoño \& Cruz, 2019). In fact, in countries of the global south, the predominant indicators for monitoring the SDGs are related to the social and economic dimensions, since the priority problems to be solved are related to income generation and poverty reduction (Boggia \& Cortina, 2010). The study of Coulibaly et al (2018) confirms this trend showing the governments of 34 African countries should prioritize SDG 8, SDG 3, and SDG 6 because these goals represent the key problems afflicting those countries. Similarly, the UNDP (2017) conducted some national studies in Asian countries, concluding that the priorities of India should be oriented to SDG 10, SDG 4, SDG 3, and SDG 1; the priorities in Bangladesh should be focused on SDG 1, SDG 3, SDG 4, SDG 6, SDG 8, and SDG 13; and Nepal should prioritize SDG 9. On the contrary, the priorities of developed countries (global 
north) have been associated with environmental problems (Londoño, 2018). However, Sánchez et al (2018) performed several case studies in municipalities belonging to the Nordic countries, finding that the prioritization was not oriented towards environmental aspects but rather at the functioning of cities as living laboratories, which is mainly related to smart and sustainable cities from the SDG 11.

This study proposes that the prioritization of SDGs at a subnational level requires coordination between national and subnational policies and the latter with the agents that constitute the territory. In this regard, Kardos (2012) called this coherence vertical and horizontal integration respectively. Similarly, Moreno \& Fidélis (2012) referred to this phenomenon as vertical-regional and horizontal-sectoral integration. This work will follow this orientation for the application of the proposed methodology. Therefore, horizontal integration (Top-down) is provided by the technical approach derived from the indicators of the national sustainable development agenda (document CONPES 3918), and vertical integration (Bottom-up) is provided by the participatory approach represented in the quality-of-life survey (perceptions of citizens).

To provide a methodology for the prioritization of SDGs at the sub-national level, the selected subnational level is required to fulfil a series of criteria. First, a national SDG framework serving as a guide for the selection of indicators at the subnational level is required, facilitating regional-vertical integration (Kardos, 2012; Moreno \& Fidélis, 2012). Colombia provides a framework of SDGs that is supported in the document CONPES 3918, defining indicators by which to assess sustainable development; and this is used as the selected guide frame. Second, the subnational level must utilize some tool that allows for horizontalsectoral integration (Kardos, 2012; Moreno \& Fidélis, 2012), thus integrating the sectors and agents that constitute the territory. The city of Medellin has a quality-of-life survey aimed at citizens to investigate priority issues to improve life quality. Third, the selected subnational level must provide availability of indicators to assess sustainable development, which also meets the city of Medellin, guaranteeing a more reliable measurement of sustainable development (Shaaban \& Scheffran, 2017). On this basis, the city of Medellin is selected to implement the proposed methodology of prioritizing SDGs using a governance approach. As shown in Figure 1, Medellin is a city located in the northwest of Colombia, South America, and represents the capital of the Antioquia State, its population is approximately 2,400,000 inhabitants.
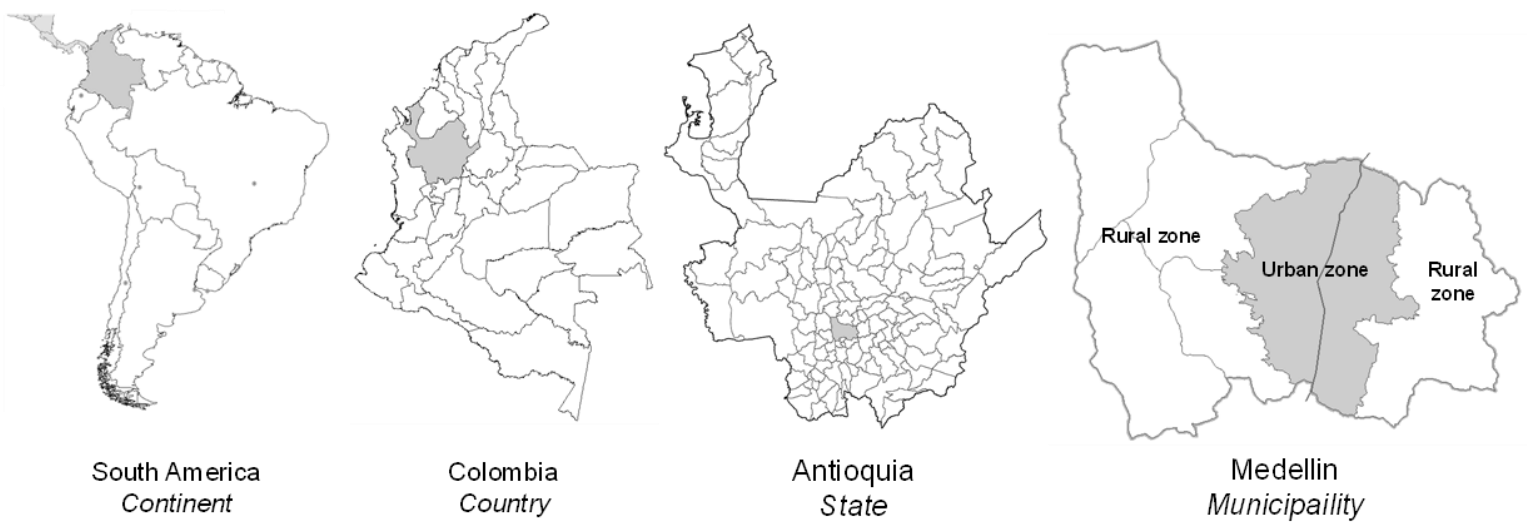

Figure 1 - Location of the city of Medellin. Source: Prepared by the Authors.

\section{Methodology}

The methodology to be implemented in this study for the prioritization of SDGs at the sub-national level is based on two types of information sources to address the technical and participatory approaches. For the technical approach, economic and social policies focused on different fields of interest in Colombia are used, represented in the CONPES (Consejo Nacional de Política Económica y Social - National Council for Economic and Social Policy) documents. Specifically, CONPES 3918 establishes the sustainable development indicators (SDIs) and strategies for the fulfillment of the 2030 Agenda and its SDGs in Colombia, simplifying 
the public management of the SDGs and generating a framework for its implementation at the subnational level.

For the participatory approach, the study was based on the "Medellín cómo vamos" program, which has as its main objective to monitor and analyze the quality of life in the city of Medellín, with a metropolitan perspective in specific sectors, and is led by an inter-institutional alliance (Non-governmental institutions, universities, business associations, private companies, foundations, compensation funds). This program includes the Quality-of-Life Survey, which is aimed at the citizens of Medellín to measure their perception of the most important aspects of the quality of life. As shown in Figure 2, a governance approach for sustainable development is provided from the articulation of technical and participatory approaches. The articulation refers to the relationship between the SDIs established in CONPES 3918 and the prioritization of these indicators based on the results of the Quality-of-Life Survey that measures citizen perception.

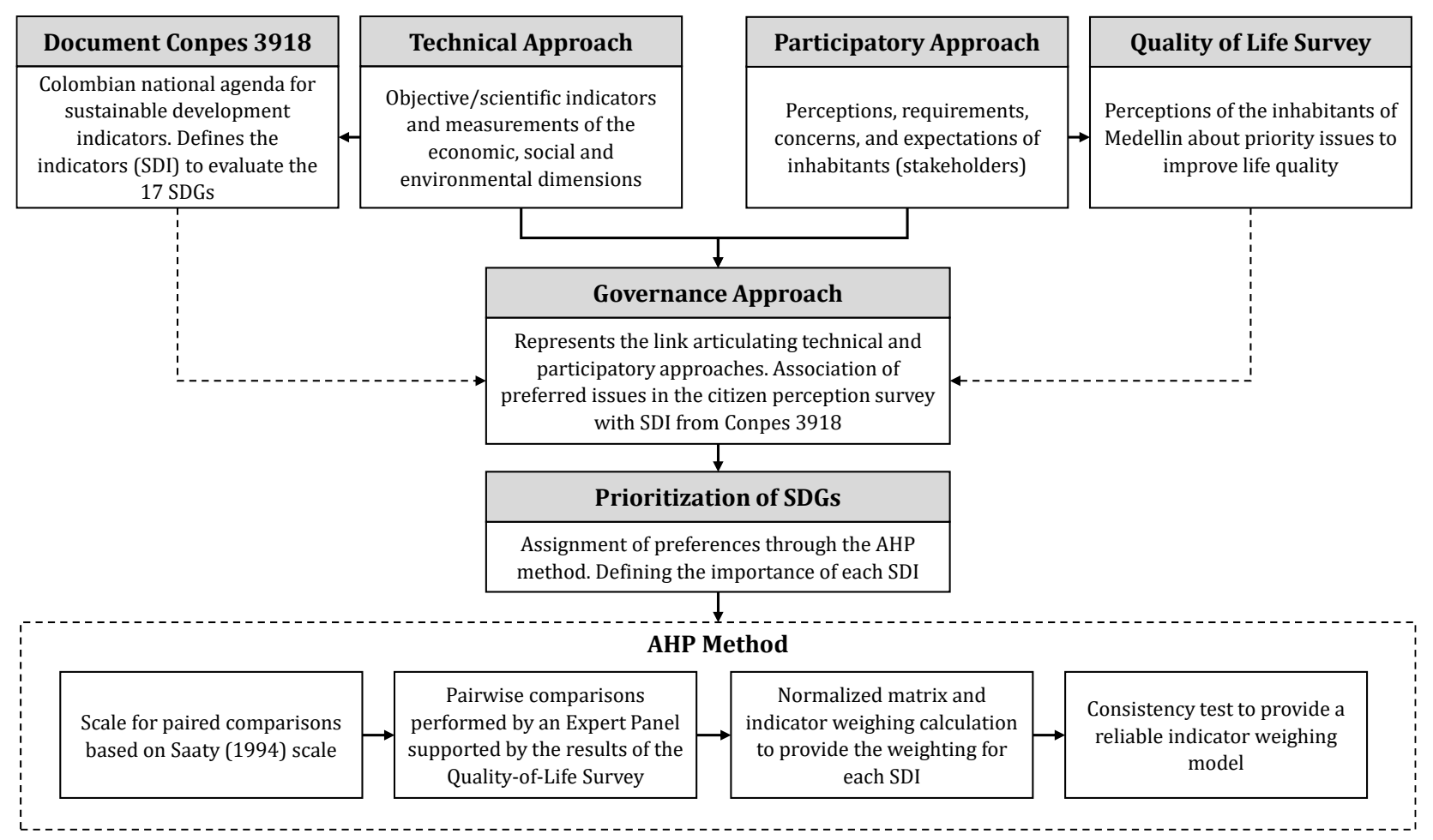

Figure 2 - Methodology for the prioritization of SDGs at the sub-national level. Source: Prepared by the Authors.

\section{Regional-vertical integration for the SDGs (CONPES 3918)}

In Colombia, the SDG agenda is supported in the document CONPES 3918, which defines the indicators that should evaluate the 17 SDGs to meet the 2030 agenda in Colombia. This exercise was conducted by the National Government of Colombia, the National Planning Department (DPN), and the National Statistics Department (Dane). The indicators contained therein are shown in Table 1. The indicators from the CONPES document serve as a guide for the sustainable development evaluation at the sub-national level in the city of Medellin and represent the technical approach because they are objective/scientific indicators (Mineur, 2007; Lyytim€aki et al., 2014). The indicators for each dimension were defined by experts from organizations like the National Government of Colombia, DPN, and Dane. To distinguish between the SDGs of the 2030 agenda and the goals defined in the Colombian national agenda (CONPES 3918), the latter will be called sustainable development indicators (SDI). 
Governance approach to the prioritization of sustainable development goals in the city of Medellin (Colombia)

Table 1 - SDGs and their indicators according to the document CONPES 3918

\begin{tabular}{lll}
\hline SDGs & Indicator defined in document CONPES 3918 & Code \\
\hline 1. No poverty & Multidimensional poverty index & SDI1 \\
2. Zero hunger & Mortality rate due to malnutrition in children under 5years & SDI2 \\
3. Good health and well-being & Maternal mortality rate & SDI3 \\
4. Quality education & Higher education coverage rate & SDI4 \\
5. Gender equality & Percentage of women in state management positions & SDI5 \\
6. Clean water and sanitation & Access to drinking water (\%) & SDI6 \\
7. Affordable and clean energy & Electric power coverage & SDI7 \\
8. Decent work and economic growth & Labor formality rate & SDI8 \\
9. Industry, innovation, and infrastructure & Households with internet access & SDI9 \\
10. Reduced inequalities & Gini coefficient & SDI10 \\
11. Sustainable cities and communities & Households with a quantitative housing deficit & SDI11 \\
12. Responsible consumption and production & Recycling rate and new use of solid waste & SDI12 \\
13. Climate action & Reduction of total greenhouse gas emissions & SDI13 \\
14. Life below water & Thousands of marine protected areas & SDI14 \\
15. Life on land & Thousands of hectares of protected areas \\
16. Peace, justice and strong institutions & Homicide rate per 100,000 inhabitants \\
17. Partnerships & The chosen indicator should reflect alliances between the & SDI17 \\
\hline
\end{tabular}

Source: Adapted from CONPES 3918.

\section{Horizontal-sectoral integration for SDGs (Quality of Life Survey in Medellin)}

The Quality-of-Life Survey of Medellin is performed every year and records the perceptions of the inhabitants of that city. In the way that it takes account of the needs and concerns of inhabitants, it is part of the participatory approach defined by authors like Holden (2011), Moreno \& Fidélis (2015), Serna et al. (2017), and Londoño (2018). The most recent Quality of Life Survey is from the year 2019; it was performed by the survey firm Ipsos Napoleón Franco, with 1531 surveys conducted based on a margin of error of 2.5\% and a confidence index of $95 \%$. The proposed methodology is based on the question: What are the most important aspects of your quality of life? The results for the answer to this question are shown in Table 2.

Table 2 - Most important aspects of the quality of life in Medellin

\begin{tabular}{ll}
\hline Most important issues of quality of life & Percentage of the population surveyed \\
\hline 1. Health & $76 \%$ \\
2. Employment & $51 \%$ \\
3. Education & $46 \%$ \\
4. Housing & $29 \%$ \\
5. Family and friends & $23 \%$ \\
6. Security & $15 \%$ \\
7. Food & $14 \%$ \\
8. Income and material possessions & $10 \%$ \\
9. Others (Recreation, equality, well-being, mobility, & $31 \%$ (on average each issue is chosen by \\
transportation, public space) & $5.1 \%$ of the population) \\
\hline
\end{tabular}

Source: Medellin quality of life survey Alcaldía de Medellín (2019).

\section{Methods for the prioritization of SDGs}

When evaluating sustainable development at different territorial scales, it is common to note the application of different weighting techniques to prioritize several SDGs (Alam et al., 2016; Ciommi et al., 
2017). To weigh the SDGs and their indicators, techniques like equal weights, linear regressions, and perception surveys can be used (Serna et al., 2017; Londoño et al., 2019). However, these methods provide some limitations as SDGs are being prioritized. In the case of equal weights, all dimensions and indicators would receive this, so there would be no prioritization. Consequently, this study considers a multicriteria method as the most indicated to establish the weights and priorities for the SDGs and their indicators (Janeiro \& Patel, 2015) because sustainable development is a process that involves people, institutions, natural resources, and the environment (Munier, 2005), indicating that its problems are multidimensional.

In this regard, Diaz-Balteiro et al., (2017) found that 93 out of 271 technical articles focused on measuring sustainability use multicriteria techniques based on the analytical hierarchical process (AHP), which was introduced by Saaty (1980). The AHP method sets preferences following a format of pairwise comparisons, supported on a fundamental verbal scale. According to Saaty (1994), the AHP method performs a preference assignment, a matrix of pairwise comparisons, and a standardized matrix, and the results must be proved by a consistency test. Therefore, the AHP allows to establish the weights and priorities for SDIs, allows prioritizing preferences (in this case based on the citizen perception survey and expert criterion), and guarantees consistency in the prioritization process.

\section{Assignment of preferences}

When it comes to preferences being assigned to SDGs, it should be remarked that the purpose of this methodology is to contribute to SDG prioritization based on a governance approach. Therefore, the technical approach from the document CONPES 3918 must be articulated with the participatory approach derived from the citizen perception survey of Medellin using an expert criterion, represented in Table 3 . Then, the preferred issues in the citizen perception survey are linked with the SDG indicators from CONPES 3918.

Table 3 - Articulation of the citizen perception survey and the indicators in document CONPES 3918 for the SDGs

\begin{tabular}{|c|c|c|}
\hline $\begin{array}{l}\text { Preferred issues in the } \\
\text { citizen perception survey }\end{array}$ & $\begin{array}{l}\text { SDI from } \\
\text { CONPES } 3918 \\
\text { (Code) }\end{array}$ & Justification \\
\hline 1. Health & $\begin{array}{l}\text { SDI3 } \\
\text { SDI17 }\end{array}$ & $\begin{array}{l}\text { One of the key indicators in the } 2030 \text { agenda in SDG } 3 \\
\text { This indicator affects human health and is the result of the } \\
\text { consensus of stakeholders }\end{array}$ \\
\hline 2. Employment & $\begin{array}{l}\text { SDI8 } \\
\text { SDI5 }\end{array}$ & $\begin{array}{l}\text { Belongs to the national agenda regarding SDG } 8 \\
\text { In the Quality-of-Life Survey, citizens mention the issue of gender } \\
\text { equality, but the indicator in document CONPES } 3918 \text { is aimed at } \\
\text { increasing female employment in state offices }\end{array}$ \\
\hline 3. Education & SDI4 & One of the key indicators found in the 2030 agenda in SDG 4 \\
\hline 4. Housing & $\begin{array}{l}\text { SDI6 } \\
\text { SDI7 } \\
\text { SDI9 } \\
\text { SDI11 }\end{array}$ & $\begin{array}{l}\text { One of the key indicators in the } 2030 \text { agenda in SDG } 6 \\
\text { One of the key indicators in the } 2030 \text { agenda in SDG } 7 \\
\text { One of the key indicators in the } 2030 \text { agenda in SDG } 9 \\
\text { Belongs to the agenda regarding SDG } 11\end{array}$ \\
\hline 5. Family and friends & & \\
\hline 6. Security & SDI16 & Belongs to the agenda regarding SDG 16 \\
\hline 7. Food & SDI2 & Belongs to the agenda regarding SDG 2 \\
\hline $\begin{array}{l}\text { 8. Income and material } \\
\text { possessions }\end{array}$ & SDI1 & Belongs to the agenda regarding SDG 1 \\
\hline 9. Others (Recreation, & SDI10 & Belongs to the agenda regarding SDG 10 \\
\hline equality, well-being, & SDI12 & Belongs to the agenda regarding SDG 12 \\
\hline mobility, transportation, & SDI13 & Belongs to the agenda regarding SDG 13 \\
\hline public space) & SDI14 & Not applicable because Medellin is a city without access to the sea \\
\hline & SDI15 & Belongs to the agenda regarding SDG 15 \\
\hline
\end{tabular}

Source: Adapted from CONPES 3918 and Medellin quality of life survey "Medellín cómo vamos" (2019). 
After articulating document CONPES 3918 with the citizen perception survey of Medellín, the importance of each SDI must be defined. For this, use is made of the original Saaty (1994) scale, which offers nine qualifications. This preference scale indicates which SDI is more important than which other, and allows us to assign weights or priorities to each goal. Table 4 shows this preference scale.

Table 4 - Scale for paired comparisons

\begin{tabular}{|c|c|c|}
\hline Intensity & Definition & Explanation \\
\hline 1 & $\begin{array}{l}\text { Equal importance } \\
\text { between both elements }\end{array}$ & Two activities contribute equally to the objective \\
\hline 3 & $\begin{array}{l}\text { Moderate importance of } \\
\text { one over another }\end{array}$ & Experience and judgment slightly favor one activity over the other \\
\hline 5 & Strong importance & Experience and judgment strongly favor one activity over the other \\
\hline 7 & Very strong importance & $\begin{array}{l}\text { Experience and judgment very strongly favor one activity over the } \\
\text { other }\end{array}$ \\
\hline 9 & Absolute importance & Experience and judgment absolutely favor one activity over the other \\
\hline $2,4,6,8$ & $\begin{array}{l}\text { Intermediate values } \\
\text { between adjacent scales }\end{array}$ & Used to represent the compromise between the priorities listed above \\
\hline
\end{tabular}

Source: Taken from Saaty (1994).

The prioritization of an SDI is engaged in by an expert panel and must ensure logical coherence in meeting transitivity criteria of preferences. Therefore, if the Health issue is preferred over Employment, and the Employment issue is preferred over Education, then the Health issue should be preferred over Education. This procedure is performed with each issue and is verified through a consistency test.

\section{Pairwise comparisons}

The AHP introduced by Saaty (1980) had as its purpose the establishment of preferences following a format of pairwise comparisons, with the support of a fundamental verbal scale that aims to define the importance of each variable concerning the others. The proposed question is this: is the item in the row more important than the item in the column? When comparing the same variable, the rating will be 1 , so the main diagonal of $A$ is equal to $1\left(\mathrm{a}_{\mathrm{ii}}=1\right.$ or $\left.\mathrm{a}_{\mathrm{j} j}=1\right)$. Below the main diagonal there are the inverse ratings to those that appear above it, and in this case, the judgment matrix contains values from 1 to 9 and their corresponding inverse values.

\section{Normalized matrix and indicator weighing calculation}

To obtain the weights for each indicator, the judgment matrix for indicators must be normalized by dividing each value over the total of the column where it belongs following Eq. (1). Next, the rows of all the standardized values ( $\mathrm{sa}_{\mathrm{ij}}$ ) are summed and divided by the number of indicators (in this case 16 ), as shown in Eq. (2), to obtain the weighting for each indicator (Wi).

$$
\begin{gathered}
s a_{i j}=\frac{a_{i j}}{\sum_{i=1}^{N} a_{i j}} \forall j \in N \\
W_{i}=\frac{\sum_{j=1}^{N} s a_{i j}}{N} \forall i \in N
\end{gathered}
$$

Once judgment matrix $A$ is completed, the problem becomes one of vectors and eigenvalues: $A w=\lambda w$, where $A$ is the reciprocal matrix of pairwise comparisons, $w$ the eigenvector that represents the ranking or priority order, and $\lambda$ the maximum own value representing a consistency measure for the judgments. 


\section{Consistency test}

To verify the consistency of the AHP, it is necessary to calculate the consistency ratio (CR) proposed by (Saaty, 1980), which is based on a consistency index (CI) and a random index (RI) as shown in Eq. (3). If CR $<0.10$, the consistency is reasonable; whereas if $\mathrm{RC}>0.10$ the hierarchical analysis model is inconsistent (Saaty, 1994), and the assignment of preferences and pairwise comparisons must be made once more to obtain a reliable indicator weighing model.

$$
C R=\frac{C I}{R I}
$$

For the consistency index Eq. (4) is used, where $\lambda \max$ is the maximum eigenvalue obtained by multiplying the total sums vector of the paired-comparisons matrix with the vector-weighted values of the normalized matrix. On the other hand, $n$ represents the number of elements of the matrix $(\mathrm{NxN})$.

$$
C I=\frac{\lambda \max -n}{n-1}
$$

The random index is taken from a standard generated at random and depends on the number of elements compared. Eq. (5) is used for obtaining the random index, where the coefficient 1.98 is used when n>10 (Aguarón \& Moreno-Jiménez, 2013).

$$
R I=\frac{1.98(n-2)}{n}
$$

\section{Results}

By articulating the scale for paired comparisons with the hierarchy of SDGs assigned in Table 3 and the support of an expert panel, it is possible to achieve the pairwise comparisons for each of the SDIs that measure sustainable development in the city of Medellin, as shown in Table 5. Then, these results were normalized using Eq. (1) obtaining the Normalized matrix shown in Table 6, and Eq. (2) was applied to these data to obtain the weights of each SDG shown in Figure 2.

Based on the results from Table 6 and figure 2, Eq. (4) and Eq. (5) were applied to obtain a CI equal to 0.061 and an RI equal to 1.733. In this manner, the consistency ratio (CR) is 0.035 , with $C R<0.10$, so the AHP model is consistent and reliable for the prioritization of SDGs. The sustainable development ideals tend towards the full achievement of all 17 SDGs, however, in real cases, this task is not easy due to the existence of opportunity costs, which require the prioritization of public investments since the Government resources are scarce. Thus, according to Figure 2, public policy priorities in the city of Medellin should be directed to those indicators with superior weight, like air quality index (SDI17), Maternal mortality rate (SDI3), labor formalization rates (SDI8), percentage of women in state management positions (SDI5) and higher education coverage rate (SDI4). These five SDIs together represent $64.55 \%$ of the priorities for sustainable development in Medellin. 
Governance approach to the prioritization of sustainable development goals in the

city of Medellin (Colombia)

Table 5 - Matrix of paired comparisons

\begin{tabular}{|c|c|c|c|c|c|c|c|c|c|c|c|c|c|c|c|c|}
\hline & SDI1 & SDI2 & SDI3 & SDI4 & SDI5 & SDI6 & SDI7 & SDI8 & SDI9 & SDI10 & SDI11 & SDI12 & SDI13 & SDI15 & SDI16 & SDI17 \\
\hline SDII & 1 & 0.5 & 0.143 & 0.2 & 0.167 & 0.25 & 0.25 & 0.167 & 0.25 & 2 & 0.25 & 2 & 2 & 2 & 0.333 & 0.143 \\
\hline SDI2 & 2 & 1 & 0.167 & 0.25 & 0.2 & 0.333 & 0.333 & 0.2 & 0.333 & 3 & 0.333 & 3 & 3 & 3 & 0.5 & 0.167 \\
\hline SDI3 & 7 & 6 & 1 & 3 & 2 & 4 & 4 & 2 & 4 & 8 & 4 & 8 & 8 & 8 & 5 & 1 \\
\hline SDI4 & 5 & 4 & 0.333 & 1 & 0.5 & 2 & 2 & 0.5 & 2 & 6 & 2 & 6 & 6 & 6 & 3 & 0.333 \\
\hline SDI5 & 6 & 5 & 0.5 & 2 & 1 & 3 & 3 & 1 & 3 & 7 & 3 & 7 & 7 & 7 & 4 & 0.5 \\
\hline SDI6 & 4 & 3 & 0.25 & 0.5 & 0.333 & 1 & 1 & 0.333 & 1 & 5 & 1 & 5 & 5 & 5 & 2 & 0.2 \\
\hline SDI7 & 4 & 3 & 0.25 & 0.5 & 0.333 & 1 & 1 & 0.333 & 1 & 5 & 1 & 5 & 5 & 5 & 2 & 0.2 \\
\hline SDI8 & 6 & 5 & 0.5 & 2 & 1 & 3 & 3 & 1 & 3 & 7 & 3 & 7 & 7 & 7 & 4 & 0.5 \\
\hline SDI9 & 4 & 3 & 0.25 & 0.5 & 0.333 & 1 & 1 & 0.333 & 1 & 5 & 1 & 5 & 5 & 5 & 2 & 0.25 \\
\hline SDI10 & 0.5 & 0.333 & 0.125 & 0.167 & 0.143 & 0.2 & 0.2 & 0.143 & 0.2 & 1 & 0.2 & 1 & 1 & 1 & 0.25 & 0.125 \\
\hline SDII 1 & 4 & 3 & 0.25 & 0.5 & 0.333 & 1 & 1 & 0.333 & 1 & 5 & 1 & 5 & 5 & 5 & 2 & 0.25 \\
\hline SDI12 & 0.5 & 0.333 & 0.125 & 0.167 & 0.143 & 0.2 & 0.2 & 0.143 & 0.2 & 1 & 0.2 & 1 & 1 & 1 & 0.25 & 0.125 \\
\hline SDI13 & 0.5 & 0.333 & 0.125 & 0.167 & 0.143 & 0.2 & 0.2 & 0.143 & 0.2 & 1 & 0.2 & 1 & 1 & 1 & 0.25 & 0.125 \\
\hline SDI15 & 0.5 & 0.333 & 0.125 & 0.167 & 0.143 & 0.2 & 0.2 & 0.143 & 0.2 & 1 & 0.2 & 1 & 1 & 1 & 0.25 & 0.125 \\
\hline SDI16 & 3 & 2 & 0.2 & 0.333 & 0.25 & 0.5 & 0.5 & 0.25 & 0.5 & 4 & 0.5 & 4 & 4 & 4 & 1 & 0.2 \\
\hline SDI17 & 7 & 6 & 1 & 3 & 2 & 5 & 5 & 2 & 4 & 8 & 4 & 8 & 8 & 8 & 5 & 1 \\
\hline Sum & 55 & 42.83 & 5.343 & 14.45 & 9.021 & 22.88 & 22.88 & 9.021 & 21.88 & 69 & 21.88 & 69 & 69 & 69 & 31.83 & 5.243 \\
\hline
\end{tabular}

Source: Prepared by the authors.

Table 6 - Normalized matrix

\begin{tabular}{|c|c|c|c|c|c|c|c|c|c|c|c|c|c|c|c|c|}
\hline & SDI1 & SDI2 & SDI3 & SDI4 & SDI5 & SDI6 & SDI7 & SDI8 & SDI9 & SDI10 & SDI11 & SDI12 & SDI13 & SDI15 & SDI16 & SDI17 \\
\hline SDII & 0.02 & 0.01 & 0.03 & 0.01 & 0.02 & 0.01 & 0.01 & 0.02 & 0.01 & 0.03 & 0.01 & 0.03 & 0.03 & 0.03 & 0.01 & 0.03 \\
\hline SDI2 & 0.04 & 0.02 & 0.03 & 0.02 & 0.02 & 0.01 & 0.01 & 0.02 & 0.02 & 0.04 & 0.02 & 0.04 & 0.04 & 0.04 & 0.02 & 0.03 \\
\hline SDI3 & 0.13 & 0.14 & 0.19 & 0.21 & 0.22 & 0.17 & 0.17 & 0.22 & 0.18 & 0.12 & 0.18 & 0.12 & 0.12 & 0.12 & 0.16 & 0.19 \\
\hline SDI4 & 0.09 & 0.09 & 0.06 & 0.07 & 0.06 & 0.09 & 0.09 & 0.06 & 0.09 & 0.09 & 0.09 & 0.09 & 0.09 & 0.09 & 0.09 & 0.06 \\
\hline SDI5 & 0.11 & 0.12 & 0.09 & 0.14 & 0.11 & 0.13 & 0.13 & 0.11 & 0.14 & 0.10 & 0.14 & 0.10 & 0.10 & 0.10 & 0.13 & 0.10 \\
\hline SDI6 & 0.07 & 0.07 & 0.05 & 0.03 & 0.04 & 0.04 & 0.04 & 0.04 & 0.05 & 0.07 & 0.05 & 0.07 & 0.07 & 0.07 & 0.06 & 0.04 \\
\hline SDI7 & 0.07 & 0.07 & 0.05 & 0.03 & 0.04 & 0.04 & 0.04 & 0.04 & 0.05 & 0.07 & 0.05 & 0.07 & 0.07 & 0.07 & 0.06 & 0.04 \\
\hline SDI8 & 0.11 & 0.12 & 0.09 & 0.14 & 0.11 & 0.13 & 0.13 & 0.11 & 0.14 & 0.10 & 0.14 & 0.10 & 0.10 & 0.10 & 0.13 & 0.10 \\
\hline SDI9 & 0.07 & 0.07 & 0.05 & 0.03 & 0.04 & 0.04 & 0.04 & 0.04 & 0.05 & 0.07 & 0.05 & 0.07 & 0.07 & 0.07 & 0.06 & 0.05 \\
\hline SDI10 & 0.01 & 0.01 & 0.02 & 0.01 & 0.02 & 0.01 & 0.01 & 0.02 & 0.01 & 0.01 & 0.01 & 0.01 & 0.01 & 0.01 & 0.01 & 0.02 \\
\hline SDI11 & 0.07 & 0.07 & 0.05 & 0.03 & 0.04 & 0.04 & 0.04 & 0.04 & 0.05 & 0.07 & 0.05 & 0.07 & 0.07 & 0.07 & 0.06 & 0.05 \\
\hline SDI12 & 0.01 & 0.01 & 0.02 & 0.01 & 0.02 & 0.01 & 0.01 & 0.02 & 0.01 & 0.01 & 0.01 & 0.01 & 0.01 & 0.01 & 0.01 & 0.02 \\
\hline SDI13 & 0.01 & 0.01 & 0.02 & 0.01 & 0.02 & 0.01 & 0.01 & 0.02 & 0.01 & 0.01 & 0.01 & 0.01 & 0.01 & 0.01 & 0.01 & 0.02 \\
\hline SDI15 & 0.01 & 0.01 & 0.02 & 0.01 & 0.02 & 0.01 & 0.01 & 0.02 & 0.01 & 0.01 & 0.01 & 0.01 & 0.01 & 0.01 & 0.01 & 0.02 \\
\hline SDI16 & 0.05 & 0.05 & 0.04 & 0.02 & 0.03 & 0.02 & 0.02 & 0.03 & 0.02 & 0.06 & 0.02 & 0.06 & 0.06 & 0.06 & 0.03 & 0.04 \\
\hline SDI17 & 0.13 & 0.14 & 0.19 & 0.21 & 0.22 & 0.22 & 0.22 & 0.22 & 0.18 & 0.12 & 0.18 & 0.12 & 0.12 & 0.12 & 0.16 & 0.19 \\
\hline
\end{tabular}

Source: Prepared by the authors. 
Governance approach to the prioritization of sustainable development goals in the city of Medellin (Colombia)

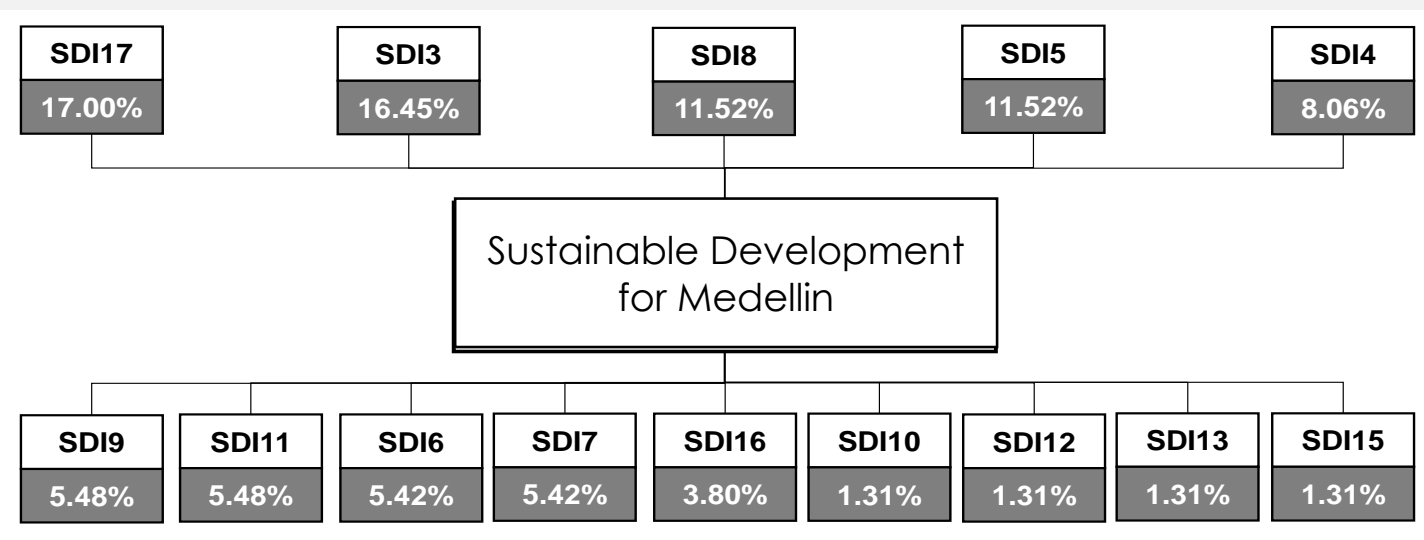

Figure 2 - SDI priorities for the city of Medellin. Source: Prepared by the Author.

\section{Discussion}

The results of this work show that the most relevant sustainable development priority for the city of Medellin is oriented to the health issue since the two indicators with the most considerable weight were SDI17 and SDI3, which belong to this issue. SDI 17 indicates that air quality is the result of the consensus derived from private, governmental, and different alliances that constitute the territory. Consequently, poor air quality constitutes a public health problem in Medellin since the city is surrounded by mountains that do not allow adequate air circulation, concentrating particulate matter inside the valley. In the case of SDI3, although maternal mortality rates are lower than the world and national average, this is still an issue that the city government must prioritize.

Likewise, this study prioritizes the issue of employment represented by the SDI8 and SDI5. In this regard, SDI8 refers to the rate of labor formality due to the high labor informality in Medellin and in Colombia, which has been accentuated during the confinement of the Covid-19 pandemic (Han, et al., 2021), so it will likely continue to persist as a priority in upcoming quality of life surveys. In the case of SDI5, which refers to gender equity when measuring the percentage of women working in public positions, it is important to improve the values of this indicator because it presents values lower than those required by the United Nations, and lower than the national average, for which it is necessary to promote the participation of women so that they can be elected for public office. The issue of education occupies the third place of preferences, represented in this study by the SDI4 for coverage of higher education. The prioritization of this indicator under the governance approach reflects the government of Medellín must provide the conditions for citizens to access higher education and prepare for the labor market, which continuously requires a qualified workforce.

According to the above, the priorities represented in SDI17, SDI3, SDI8, SDI5, and SDI4 reflect the sustainable development priorities in the city of Medellín correspond respectively to SDG 3 (Health and well-being), SDG 8 (Decent work and economic growth), and SDG 4 (Quality education). This order is granted explicitly for the city of Medellín, and it does not have to be the same for all the cities of the Aburrá Valley or other cities in Colombia, since this prioritization depends on the realities and particularities of each locality. Although the priorities of developing countries have focused on social and economic dimensions, and on environmental problems in developed countries (Boggia \& Cortina, 2010; Tanguay et al., 2010), this cannot be generalized when prioritizing the SDGs since the SDGs are multidimensional, and they can affect in diverse ways the specific realities of both developed countries in the global north and developing countries in the global south.

For example, in Hunan, Province of China, a study showed that SDG priorities varied from urban to provincial, however, the trend shows that priorities focus on sustainable cities and communities (SDG 11), life on earth (SDG 15), decent work and economic growth (SDG 8), and responsible consumption and production (SDG 12) (Han et al., 2021). This study coincides with the work of Sánchez et al (2018) for different cities in Nordic countries, identifying the trend of prioritizing the SDGs is centered on SDG 11 
(Sustainable cities and communities). Likewise, the study of Abubakar \& Aina (2019) shows that SDG 11 is among the main priorities in the urban areas of Nigeria due to the size of the population and the problems of urban settlements (Abubakar \& Aina, 2019). Consequently, in cities of the developed north, in middleincome cities like Hunan, or cities belonging to the developing south like those belonging to Nigeria, there may be a coincidence in the prioritization of SDGs, in this case, SDG 11, although the needs that encourage such prioritization differ in each context.

On the other hand, in a study performed in sub-Saharan African locations, one of the recurrent problems is related to access to energy, which is why the achievement of SDG 7 (Affordable and clean energy) is prioritized (Chirambo, 2018). In Jakarta, the capital of Indonesia, alternatives are required for the use of groundwater, which is why they prioritize SDG 6 (clean water and sanitation), considering the particularities of overpopulation, sanitation, and wastewater management in Jakarta (Kooy, Walter, \& Prabaharyaka, 2018). Similarly, the work of Horn \& Grugel (2018) in the city of Quito, Ecuador, indicates that the priorities are focused on SDG 10 (Reduction of inequalities). This last work addresses a type of country and city similar to our study since Ecuador represents a middle-income country as is Colombia, and the work of Horn and Gruge (2018) considers the national policy to establish the subnational policy of sustainable development in Quito. However, our study considers the participatory component when selecting priorities, providing an approach of governance for sustainable development.

Therefore, the contribution of our work focuses on the use of an approach of governance for sustainable development based on the articulation of technical and participatory approaches, representing the technical approach through the national policy of sustainable development from CONPES 3918, guiding subnational policy (vertical integration), and representing the participatory approach through the quality of life survey, which collects the perceptions of citizens, reflecting the integration of actors at the subnational level (horizontal integration). Another contribution of this study is to allow the ranking of the SDGs to provide priorities in sustainable development. In this regard, in the study of Lamichhane et al (2021), each SDG received the same weight to perform a comparative analysis of sustainable development in OECD countries. Likewise, the work of Londoño and Cruz (2019) evaluated the level of sustainable development in the nine subregions of Antioquia (Colombia), assigning the same SDGs weighing to each subregion, limiting the prioritization of SDGs according to the specific needs of each subregion. Therefore, some particularities of each subregion could be omitted, and precisely our study allows identifying the priority issues in each locality related to sustainable development through a governance approach.

It could be considered that this study presents a limitation since as the number of indicators to prioritize increases, the analysis by paired comparisons becomes more complex, therefore increasing the size of the paired comparisons matrix and the normalized matrix shown in Tables 5 and 6. For example, the prioritization of the 232 indicators of the 2030 agenda would imply a complex procedure involving a $232 \mathrm{X}$ 232 paired-comparisons matrix. However, this study assumes the positions of Jain \& Tiwari (2017), and Shaaban \& Sheffran (2017), who recommend selecting a manageable number of indicators, facilitating public management and the monitoring of sustainable development policies. Consequently, this study adopted the Colombian national agenda defined in the document CONPES 3918 as a reference for sustainable development, proposing an indicator for each SDG and then prioritizing 17 indicators instead of 232 .

\section{Conclusions}

This study contributes to a reduction in the deficit of investigations oriented towards the prioritization of SDGs are concerned. The application of this work at a subnational scale supported the integration of a technical approach with a participatory approach, providing a practical tool for the governance of sustainable development. For this, the countries of the municipalities to be analyzed must have a national sustainable-development agenda, and the municipality must utilize a tool to allow for the participation of agents that constitute the territory. 
In the case of Medellín, for the technical approach, the relationship between national and subnational policies (vertical-regional integration) took as reference the document CONPES 3918, which defines Colombia's national agenda on sustainable development. For the participatory approach, the relationship between the subnational government and the agents that constitute territory (horizontal-sectoral integration) was supported in the citizen perception survey of Medellin city. The proposed tool allowed it to be established that public-policy priorities for sustainable development should be focused on the air quality index, maternal mortality rate, labor formalization rates, percentage of women in state management positions, and higher education coverage rate since those indicators presented superior weights. Although the integration of technical and participatory approaches represents a component of governance, the Mayor's Office of Medellin must improve its communication with citizens and generate processes of citizen education for sustainable development to achieve significant progress in this matter.

The proposed prioritization model for sustainable development proved to be consistent, so it can be replicated at other latitudes for prioritizing public policy at the subnational level. Therefore, this study can be implemented in other cities worldwide, adopting the quality-of-life surveys of each specific city, with which different results are expected in the prioritization due to the different needs and circumstances that each city faces, diverse cultures, geographic, topographic, environmental, and economic conditions, among others.

Finally, this work is valuable in respect of the advancement of the state of the art of academic works oriented towards the prioritization of SDGs. Likewise, this type of prioritization is effective in complementing methodologies that aim to evaluate sustainable development through composite indices, specifically in the indicator weighting phase that then allows for the aggregation of indicators. Future works should expand the governance approach proposed in this study by including monitoring and feedback to citizens on the prioritization of SDIs and the results obtained in the measurement of sustainable development at the subnational level.

\section{References}

Abubakar, I. R., \& Aina, Y. A. (2019). The prospects and challenges of developing more inclusive, safe, resilient and sustainable cities in Nigeria. Land Use Policy, 87, 104105. https://doi.org/10.1016/j.landusepol.2019.104105

Aguarón, J., \& Moreno-Jiménez, J. (2013). Open educational resources in distance education: Exploring open learning in academic practice. European Journal of Operational Research, 147(1), 137-145. http://doi.org/10.1016/S03772217(02)00255-2

Aina, Y. A., Wafer, A., Ahmed, F., \& Alshuwaikhat, H. M. (2019). Top-down sustainable urban development? Urban governance transformation in Saudi Arabia. Cities, 90(February), 272-281. https://doi.org/10.1016/j.cities.2019.03.003

Alam, M., Dupras, J., \& Messier, C. (2016). A framework towards a composite indicator for urban ecosystem services. Ecological Indicators (60), 38-44. http://doi.org/10.1016/j.ecolind.2015.05.035

Alcaldía de Medellín. (2019). Encuesta de percepción ciudadana de Medellín. Medellín: IPSOS.

Angeon, V., \& Bates, S. (2015). Reviewing composite vulnerability and resilience indexes: A sustainable approach and application. World Development (72), 140-162.

Asi, Y., \& Williams, C. (2018). The role of digital health in making progress toward SustainableDevelopment Goal (SDG) 3 in conflict-affected populations. International Journal of Medical Informatics, 114, 114-120. 10.1016/j.ijmedinf.2017.11.003

Banerjee, O., Cicowiez, M., Horridge, M., \& Vargas, R. (2019). Evaluating synergies and trade-offs in achieving the SDGs of zero hungerand clean water and sanitation: An application of the IEEM Platform to Guatemala. Ecological Economics, 161, 280-291. https://doi.org/10.1016/j.ecolecon.2019.04.003

Biggeri, M., Clark, D., Ferrannini, A., \& Mauro, V. (2019). Tracking the SDGs in an 'integrated' manner: A proposal for a new indexto capture synergies and trade-offs between and within goals. World Development, 122, 628-647.

https://doi.org/10.1016/j.worlddev.2019.05.022 
Boggia, A., \& Cortina, C. (2010). Measuring sustainable development using a multi-criteria model: A case study. Journal of Environmental Management, 91, 2301-2306. http://doi.org/10.1016/j.jenvman.2010.06.009

Cassar, L., Conrad, E., Bell, S., \& Morse, S. (2013). Assessing the use and influence of sustainability indicators at the European periphery. Ecological Indicator, 35, 52-61. https://doi.org/10.1016/j.ecolind.2012.07.011

Chirambo, D. (2018). Towards the achievement of SDG 7 in sub-Saharan Africa: Creating synergies between Power Africa, Sustainable Energy for All and climate finance in-order to achieve universal energy access before 2030. Renewable and Sustainable Energy Reviews, 94, 600-608. https://doi.org/10.1016/j.rser.2018.06.025

Ciommi, M., Gigliarano, C., Emili, A., Taralli, S., \& Chelli, F. (2017). A new class of composite indicators for measuring wellbeing at the local level: An application to the Equitable and Sustainable Well-being (BES) of the Italian Provinces. Ecological indicators, (76), 281-296. http://doi.org/10.1016/j.ecolind.2016.12.050

CONPES. (2018). Conpes 3918 estrategia para la implementación de los objetivos de desarrollo sostenible (ODS) en Colombia. Bogotá: Conpes. Obtenido de https://colaboracion.dnp.gov.co/CDT/Conpes/Econ\%C3\%B3micos/3918.pdf

Coulibaly, M., Ségorbah, K., \& Logan, C. (2018). Taking stock: Citizen priorities and assessments three years into the SDGs. Afrobarometer Policy Paper, (51), 1-35.

De Guimarães, J. C. F., Severo, E. A., Felix Júnior, L. A., Da Costa, W. P. L. B., \& Salmoria, F. T. (2020). Governance and quality of life in smart cities: Towards sustainable development goals. Journal of Cleaner Production, 253.

https://doi.org/10.1016/j.jclepro.2019.119926

Diaz-Balteiro, L., González-Pachón, J., \& Romero, C. (2017). Measuring systems sustainability with multi-criteria methods: A critical review. European Journal of Operational Research, 2(258), 607-616. http://doi.org/10.1016/j.ejor.2016.08.075

Elder, M., \& Høiberg, S. (2019). The Design of Environmental Priorities in the SDGs. Global Policy, 10, 70-82. 10.1111/17585899.12596

Etzkowitz, H., \& Leydesdorff, L. (2000). The dynamics of innovation: from National System and Mode 2 to Triple helix of university-industry-goverment relations. Research Policy, 29(2), 109-123. 10.1016/S0048-7333(99)00055-4

Flutar, M. (2012). Sustainable development - a territorial development premise of Galați. Procedia - Social and Behavioral Sciences, 46, 1506 - 1509. https://doi.org/10.1016/j.sbspro.2012.05.330

Han, Z., Jiao, S., Zhang, X., Xie, F., Ran, J., Jin, R., \& Xu, S. (2021). Seeking sustainable development policies at the municipal level based on the triad of city, economy and environment: evidence from Hunan province, China. Journal of Environmental Management, 290, 112554. https://doi.org/10.1016/j.jenvman.2021.112554

Holden, M. (2011). Public participation and local sustainability: questioning a common agenda in urban governance. Int. J. Urban Reg. Res, 35(2), 312-329. https://doi.org/10.1111/j.1468-2427.2010.00957.x

Holman, N. (2009). Incorporating local sustainability indicators into structures of local governance: a review of the literature. Local Environment, 14(4), 365-375. https://doi.org/10.1080/13549830902783043

Horn, P., \& Grugel, J. (2018). The SDGs in middle-income countries: Setting or serving domestic development agendas? Evidence from Ecuador. World Development, 109, 73-84. https://doi.org/10.1016/j.worlddev.2018.04.005

Jain, D., \& Tiwari, G. (2017). Sustainable mobility indicators for Indian cities: Selection methodology and application. Ecological Indicators, 10(79), 310-322. https://doi.org/10.1016/j.ecolind.2017.03.059

Janeiro, L., \& Patel, M. (2015). Choosing sustainable technologies. Implications of the underlying sustainability paradigm in the decision-making process. Journal of Cleaner Production, (105), 438-446. http://doi.org/10.1016/j.jclepro.2014.01.029

Kardos, M. (2012). The reflection of good governance in sustainable development strategies. Procedia - Social and Behavioral Sciences, 58, 1166-1173. https://doi.org/10.1016/j.sbspro.2012.09.1098

Kooy, M., Walter, C. T., \& Prabaharyaka, I. (2018). Inclusive development of urban water services in Jakarta: The role of $\mathrm{f}$ groundwater. Habitat International, 73, 109-118. https://doi.org/10.1016/j.habitatint.2016.10.006

Lamichhane, S., gilmez, G. E., Gedik, Ridvan, B. M., \& Erenay, B. (2021). Benchmarking OECD countries' sustainable development performance: A goal-specific principal component analysis approach. Journal of Cleaner Production, 125040. https://doi.org/10.1016/j.jclepro.2020.125040 
Londoño, A. (2018). Metodología y evaluación del desarrollo sostenible de las subregiones que integran el departamento de Antioquia (Colombia), bajo un enfoque sistémico inter-temático y multicriterio. Manizales: Universidad de Manuzales.

Londoño, A., \& Cano, J. A. (2021). Economic regulation oriented to the sharing economy: an approach from target 10.3 of the 2030 agenda. Journal of Cleaner Production, In press, 127342. https://doi.org/10.1016/j.jclepro.2021.127342

Londoño, A., \& Cruz, J. G. (2019). Evaluation of sustainable development in the sub-regions of Antioquia (Colombia) using multi-criteria composite indices: A tool for prioritizing public investment at the subnational level. Environmental Development, (32), 1-22. https://doi.org/10.1016/j.envdev.2019.05.001

Lyytim€aki, J., Gudmundsson, H., \& Sørensen, C. (2014). Russian Dolls and Chinese Whispers: two perspectives on the unintended effects of sustainability indicator. Sustainable Development (22), 84-94. https://doi.org/10.1002/sd.530

Mineur, E. (2007). Toward Sustainable Development: indicator as a tool of local governance. Sweden: Print \& Media, Umeå University.

Moreno, S., \& Fidélis, T. (2012). A proposal to explore the role of sustainability indicators in local governance contexts: The case of Palmela, Portugal. Ecological Indicators, (23), 608-615. https://doi.org/10.1016/j.ecolind.2012.05.003

Moreno, S., \& Fidélis, T. (2015). Local sustainability indicators in Portugal: assessing implementation and use in governance contexts. Journal of Cleaner Production, (86), 289-300. https://doi.org/10.1016/j.jclepro.2014.08.002

Moreno, S., Fidélis, T., \& Ramos, T. (2014). Measuring and comparing local sustainable development through common indicators: Constraints and achievements in practice. Cities, (39), 1-9. https://doi.org/10.1016/j.cities.2014.02.003

Munier, N. (2005). Introduction to sustainability. Road to a better future. Netherlands: Springer.

Nam-Chol, O., \& Kim, H. (2019). Towards the $2{ }^{\circ} \mathrm{C}$ goal: Achieving Sustainable Development Goal (SDG) 7 inDPR Korea. Resources, Conservation and Recycling, 150, 1-2. https://doi.org/10.1016/j.resconrec.2019.104412

Novo, M. (2009). La educación ambiental, una genuina educación para el desarrollo sostenible. Revista de Educación, 195217. http://www.educacionyfp.gob.es/revista-de-educacion/inicio.html

Omri, A., \& Ben Mabrouk, N. (2020). Good governance for sustainable development goals: Getting ahead of the pack or falling behind? Environmental Impact Assessment Review, 83(February), 106388.

https://doi.org/10.1016/j.eiar.2020.106388

Saaty, T. (1994). How to make a decision: the analytic hierarchy process. Interfaces, 6(24), 19-43.

https://doi.org/10.1016/0377-2217(90)90057-I

Saaty, T. L. (1980). The analytic hierarchy process. New York: McGraw Hill.

Sachs, J. D., Schmidt-Traub, G., Mazzucato, M., Messner, D., Nakicenovic, N., \& Rockström, J. (2019). Six Transformations to achieve the Sustainable Development Goals. Nature Sustainability, 2(9), 805-814. https://doi.org/10.1038/s41893-0190352-9

Samuel, V., Agamuthu, P., \& Hashim, M. (2013). Indicators for assessment of sustainable production: A case study of the petrochemical industry in Malaysia. Ecological Indicators, .24, 392-402. https://doi.org/10.1016/j.ecolind.2012.07.017

Sánchez, N., Penje, O., \& Slätmo, E. (2018). Global goals for local priorities: The 2030 Agenda at local level. Stockholm: Nordregio. doi.org/10.30689/R2018:2.1403-2503

Serna, C., Londoño, A., \& Vélez, O. (2017). Subnational governance model from the integration of online media and social networks: The case of Medellin City, Colombia. En R. Ryan, \& E. Schoburgh, Handbook of Research on Sub-National Governance and Development. (pp. 483-498). IGI Global.

Shaaban, M., \& Scheffran, J. (2017). Selection of sustainable development indicators for the assessment of electricity production in Egypt. Sustainable Energy Technologies and Assessments (22), 65-73.

https://doi.org/10.1016/j.seta.2017.07.003

Srivastava, A. (2018). Standardizing evaluation process: Necessary for achieving SDGs-A case study of India. Evaluation and Program Planning, 69, 118-124. https://doi.org/10.1016/j.evalprogplan.2018.05.001

Tanguay, G., Rajaonson, J., Lefebvre, J., \& Lanoie, P. (2010). Measuring the sustainability of cities: An analysis of the use of local indicators. Ecological Indicators, 10, 407-418. https://doi.org/10.1016/j.ecolind.2009.07.013 
Governance approach to the prioritization of sustainable development goals in the city of Medellin (Colombia)

UNDP. (2017). https://www.asia-pacific.undp.org. Obtenido de https://www.asia-pacific.undp.org: https://www.asiapacific.undp.org/content/rbap/en/home/library/sustainable-development/country-briefs-on-sdg-integration-intoplanning.html

Vanham, D. et al. (2018). Physical water scarcity metrics for monitoring progress towards SDG target 6.4: An evaluation of indicator 6.4.2 "Level of water stress". Science of the Total Environment, 613-614, 218-232.

https://doi.org/10.1016/j.scitotenv.2017.09.056

Vazquez-Brust, D., Piao, R. S., de Melo, M. F. de S., Yaryd, R. T., \& M. Carvalho, M. (2020). The governance of collaboration for sustainable development: Exploring the "black box." Journal of Cleaner Production, 256, 120260.

https://doi.org/10.1016/j.jclepro.2020.120260

Editor responsável: Fábio Duarte

Received: Aug. 06th 2020

Approved: Jul. 15 th 2021 